\title{
Do euglossine females reside in a single nest? Notes on Euglossa cordata (Hymenoptera: Apidae: Euglossini)
}

\author{
David S. Nogueira' (D), Arianne M. Cavalcante ${ }^{2}$ (1) , Maria da C. Parente ${ }^{2}$ (D), \\ Alipio J. S. Pacheco Filho2 (1), Breno M. Freitas² (1)
}

1. Instituto Nacional de Pesquisas da Amazônia, Campus 2, Av. André Araújo, 2936, Petrópolis, 69067-375 Manaus, AM, Brazil (davidsn@zootecnista.com.br). 2. Universidade Federal do Ceará, Departamento de Zootecnia, Laboratório de Abelhas, Av. Mister Hull, s/n, Pici, 60455-760 Fortaleza, CE, Brazil.

Received 4 July 2018

Accepted 10 April 2019

Published 23 May 2019

DOI 10.1590/1678-4766e2019016

\begin{abstract}
Euglossa Latreille, 1802 do not live in large colonies, and these are usually maintained or "reactivated" by new females, subordinate to their mother, which construct and provision brood cells. This study aimed to obtain information about the natural history of Euglossa cordata (Linnaeus, 1758) specially focusing on nest behavior. Our specific objective was to answer the following question: do E. cordata females reside in a single nest? We construct 14 artificial nesting boxes and made them available for E. cordata bees in natural environment for seven months. During this time, we use a re-marking method to identify bee fidelity to a single nest box. More specifically, we record bee permanence in the nests, the time bees take to provision brood to new cells and the time taken to offspring emergence. A total of 12 boxes were colonized by E. cordata and 23 cells were built in an average of $9.78 \pm 11$ days per cell. Eleven females emerged from the cells in $48.6 \pm 11$ days. Although adult females moved between nests and sometimes used multiple nests at the same time, E. cordata showed a relatively high fidelity to a single nest ( $81.1 \%$ of the female bees stayed in a single nest more than $50 \%$ of time).
\end{abstract}

KEYWORDS. Female nest fidelity, bee emergence, orchid bee.

RESUMO. As fêmeas de euglossine residem em um único ninho? Notas sobre Euglossa cordata (Hymenoptera: Apidae: Euglossini). Abelhas Euglossa Latreille, 1802 não vivem em grandes colônias, e estas geralmente são mantidas ou "reativadas" por novas fêmeas, subordinadas à mãe, que constroem e fornecem células de cria. Este estudo teve como objetivo obter informações sobre o tempo que as abelhas levam para prover novas células, sobre a emergência e permanência das abelhas nos ninhos, bem como o número de ninhos construídos por cada uma. Durante sete meses observamos fêmeas em 14 caixas vazias de madeira $(5,7$ x 5,7 x 7,0 cm), disponibilizadas para nidificação das abelhas. O método de remarcação foi utilizado quando uma abelha foi encontrada pela primeira vez nas caixas ou para cada nova abelha filha após a sua emergência. Um total de 12 caixas foi colonizada por Euglossa cordata (Linnaeus, 1758) e 23 células foram construídas em 9,78 \pm 11 dias por célula. Onze fêmeas emergiram das células em 48,6 \pm 11 dias. Dois imaturos morreram e dois foram parasitados por Bombyliidae. Apesar de que as fêmeas adultas de $E$. cordata moveram-se entre ninhos e às vezes usaram vários ninhos de uma só vez, elas demonstraram uma fidelidade relativamente alta a um único ninho ( $81.1 \%$ dessas fêmeas permaneceram mais de $50 \%$ do tempo em um único ninho).

PALAVRAS-CHAVE. Fidelidade de nidificação, emergência de abelha, abelha das orquídeas

Euglossine females, also called orchid bees, are Neotropical and composed of five genus: Aglae Lepeletier \& Serville, 1825, Eufriesea Cockerell, 1908, Euglossa Latreille, 1802, Eulaema Lepeletier, 1941 and Exaerete Hoffmannsegg, 1817 (RAMíreZ et al., 2002; MicheNER, 2007). Most species do not live in large colonies and some reside in small ones, making them solitary or somewhat social. When they exhibit social behavior, they may present different levels of sociality, but many coexist in a nest with their mother and sisters (RoubiK \& HANSON, 2004; Michener, 2007).

Several studies of euglossine nest structure and nesting habits demonstrate they use pre-existing cavities, both in the wild and in urban areas (GARÓFALO, 1992; GARÓFALO et al., 1998; Ramírez et al., 2002; Augusto \& Garófalo, 2004; Carvalho-Filho \& Oliveira, 2017). In addition, these nests can be constructed on aerial substrates (fixed on shrubs, leaves, branches and bromeliad stolons), in nests abandoned by other animals (e.g. wasps and termites) and in subterranean cavities (AUGUSTO \& GARÓFALO, 2007; BoFF \& Alves-Dos-Santos, 2018).

Like social bees and certain solitary bees, the Euglossini are considered long-lived in their adult life (Michener, 1974). Euglossa is the genus with the greatest number of species, 122 valid ones, and can occur from southern United States to Argentina (Augusto \& GARófalo, 2004; SKov \& Wiley, 2005; ANDRADE-Silva \& NASCimento, 2012; Moure et al., 2012). ACKerman \& Montalvo (1985) reported several studies based on the marking and recapture of males and pointed that Euglossa ignita Smith, 1874 completed its life cycle between only 30 and 60 days. It is undeniable the necessity for collecting and analyzing additional data on the longevity of Euglossini bees (ANDRADE-SiLva \& 
NASCimento, 2012) because it varies among the species and long-term studies may be important to understand their life cycle (Boff et al., 2017).

Although many euglossines seem solitary, in some cases more than one female is found inside a nest, which is often called parasocial behavior (GARÓFALO, 1985; AUGUSTO \& GaRófalo, 2011). Studies on the nesting behavior of Euglossa cordata (Linnaeus, 1758) reveal that nests with several females result from the reuse of nesting sites by daughters when the mother is still alive, or even among unrelated females, in which the older female establishes dominance in relation to the others (GARÓFALO, 1985, Augusto \& Garófalo, 2011).

The dominant female starts guarding the nest and rarely abandons it. While in the nest, she lays eggs in the cells which are usually provisioned by her subordinates (GArófalo, 1985). In some species of Euglossa, during the nest reactivation, the dominant female displays agonistic behavior towards the subordinate. Additionally, the dominant can open cells and eat the egg laid by the subordinate bee (GARÓFALO, 1985; RAMÍREZ et al., 2002; Augusto \& Garófalo, 2004, 2011; Andrade-Silva \& NASCIMENTO, 2012; FreIRIA et al., 2017a). It is assumed that this behavior may vary among females of a single species within the nest. ANDRADE et al. (2016) observed that unrelated individuals were accepted within a nest and that dominant females ate their eggs according to the degree of kinship with the subordinate females. Boff et al. (2015) noted that the social nest can benefit from the presence of subordinate females acting as guards against predators or parasites in $E$. viridissima Friese, 1899; as Soucy et al. (2003) also noted for E. hyacinthina Dressler, 1982. Furthermore, in E. annectans Dresler, 1982 females express both communal and primitively eusocial behaviors. For example, egg consumption and then laying by the parasite or egg-eating individual is done by several females occupying the nest at the same time (BofF et al., 2017).

In terms of nesting behavior, SANTOS \& BofF (2010) and Boff et al. (2015) believe that the close presence of nonspecific or conspecific (E. annectans and E. viridissima, respectively) nests may permit cleptobiotic behavior, such as the stealing of resin. Here, we aimed to obtain information about the natural history of Euglossa cordata specially focusing on nest behavior. Our specific objective was to answer the following question: do E. cordata females reside in a single nest?

\section{MATERIAL AND METHODS}

The study was carried out in the Setor de Abelhas, Centro de Ciências Agrárias, Universidade Federal do Ceará (UFC), Fortaleza, Ceará (344’33.40”S, 38³4’45.81”W). The climate is warm, tropical subhumid, with a rainy period from January to May. The mean annual rainfall is $1338 \mathrm{~mm}$ and mean temperature $27^{\circ} \mathrm{C}$. The study area is "Mata de Tabuleiro" or coastal zone (IPECE, 2016).

The monitoring of $E$. cordata was conducted for a period of seven months, July 2013 to January 2014, using 14 wooden boxes of medium density fiberboard (Fig. 1), with an entrance hole of $0.8 \mathrm{~cm}$ in diameter. The box internal measurements were $5.7 \times 5.7 \times 7 \mathrm{~cm}$ and they were kept in rows of seven boxes each, with the entrances facing opposite directions, $12 \mathrm{~cm}$ between them and between rows. They were kept in a natural environment, elevated $1 \mathrm{~m}$ from the ground, on a wooden frame and protected from direct sunlight and rainfall by a roof installed $80 \mathrm{~cm}$ above them.

All bees found in the boxes for the first time (whether nesting, visiting or emerging) were marked with different labels. New female bees were marked after gradual cooling. It was then possible to glue a paper label with superglue on

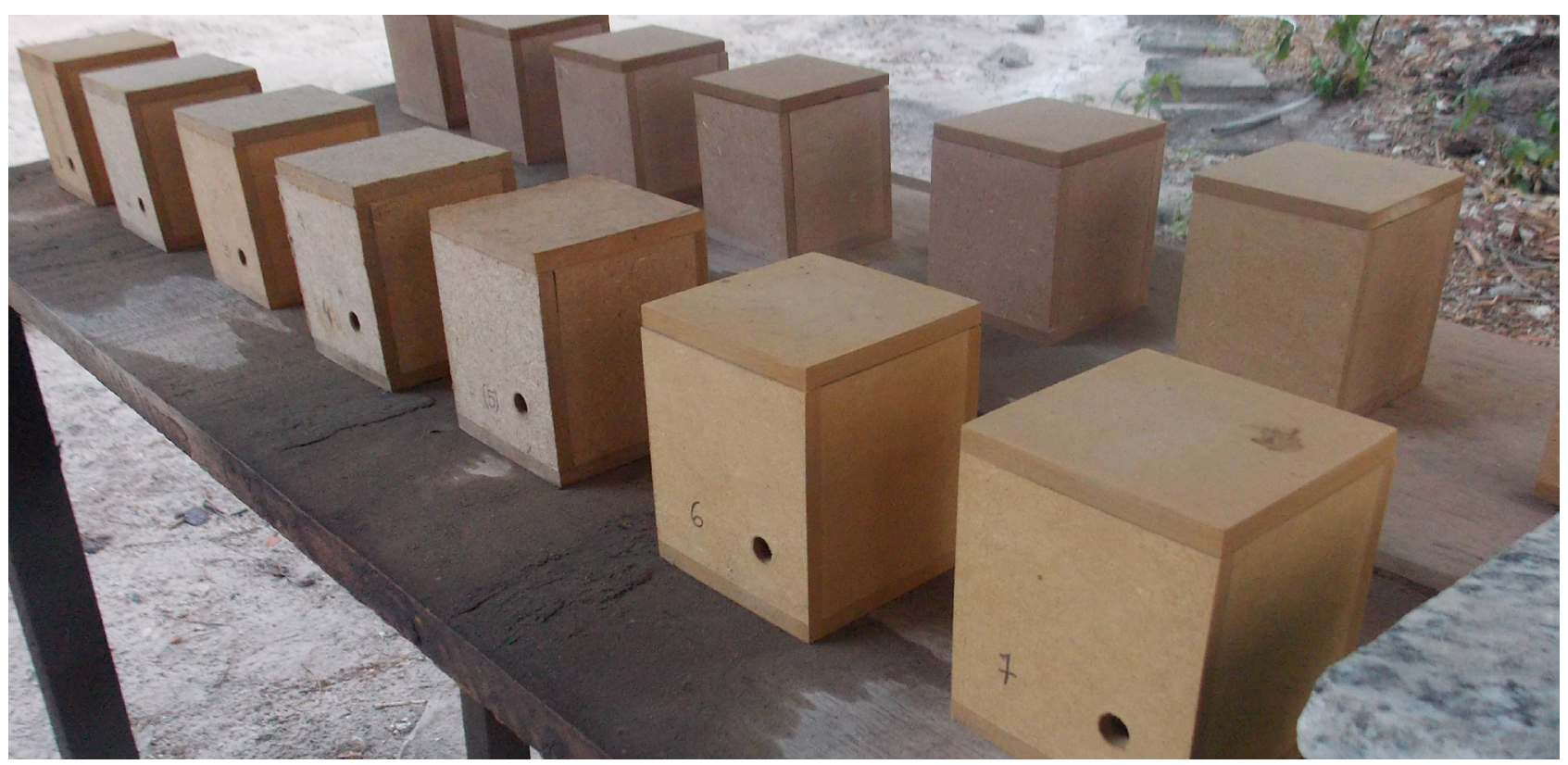

Fig. 1. Boxes of medium density fiberboard used in the study. 
the dorsal thorax. After that, each bee was released in the box which it was captured. Bees nesting were monitored once a day by direct observation and their presence recorded in late afternoon, after foraging activity ceased. The records were taken five days a week by opening the boxes and direct observation of the number of cells (empty and closed), cells being provisioned and bees present. The period of time each bee was observed in a box as described here varied according to the number of days it was seen in a box.

Bees were captured and marked when they first appeared in the boxes. This reflected directly on the cells with newly emerged bees. For example, by following the expected egg-to-adult period of a bee, when we noticed that a cell was open and a bee had emerged when we were not observing it, we assumed that any unmarked bee in that same or any of the other nests was the emerged bee, and it was captured and marked accordingly. Only when an unmarked bee was seen in any of the nests but with no emergence in any cell, we consider that this new bee emerged from an external nest in the environment.

The permanence of the bees was assessed using two parameters: 1 . Duration, measured as days a bee was observed in a given box; 2 . Time observed in the study, until the last record of that bee in the boxes. For example, if a bee spent ten days in the same box, was not seen for another two days, and then returned to the box, the time observed in the study was 12 days.

Bee fidelity to a nest box was the percentage of the days a female bee was present in a given box in relation of her duration in the study. The bee was considered faithful, if it stayed in a single nest more than $50 \%$ of time that this specific bee remained in the study.

\section{RESULTS}

A total of 43 bees were marked (from boxes or from outside - surrounding environment), but only those that did not abandon the boxes were considered in this study ( $\mathrm{n}=$ 22) (Fig. 2; Tab. I). Twelve of the 14 boxes were used and one (491 observations), two (31 observations) and three (4 observations) bees were recorded at the same time in the same box. Bees initiated nesting by closing the box entrance and accumulating resin inside the box. Out of the 14 boxes of the study, only 10 presented provisioned cells: $\mathrm{B} 1=6 ; \mathrm{B} 2=2$; $\mathrm{B} 3=1$ (parasitized); $\mathrm{B} 4=2$ (one parasitized, one dead); $\mathrm{B} 5=3$; $\mathrm{B} 6=3 ; \mathrm{B} 7=1 ; \mathrm{B} 8=2$ (one dead); $\mathrm{B} 9=1 ; \mathrm{B} 11=2$.

Time taken by bees to supply a cell. The time taken by bees to supply a cell $(n=23)$ was measured from the day the bee started building the cell until it was closed. This time was measured while there were bees working inside the nest and the mean period to finish a cell was 9.78 days ( 1 to 46 days, $\mathrm{SD}=11$ ). The bees built 23 cells in total, but the last three cells demanded many more days to be finalized than the 20 cells built previously: cells number 21 and 22 were parasitized, and the non-parasitized cell (number 23) took 46 days to be finished because three females occupied the nest and worked on this cell for different periods of time $(9,26$ and 5 days, respectively) prior to abandon it, until its final reactivation and cell provisioning and closure by a forth female (6 days) (Fig. 3). It is noteworthy that the bee that worked the 26 days in the same cell remained for a few days in the nest with the provisioned cell without finalizing it.

Bee emergence and mortality. During this study, 11 females emerged from the 23 cells $(47.8 \%)$, and there was no emergence of males in this period; of the remaining 12 cells, eight (34.7\%) produce no emergence (these cells were not opened until the completion of the total observation period), two were parasitized and bees died in the other two cells. Therefore, it was not possible to estimate the sex ratio. The egg-to-adult period for females ranged from 31 to 76 days (mean $=48.6$; $\mathrm{SD}=11 ; \mathrm{n}=11$ ), and six of them did not return to the boxes after being marked.

In our study bee mortality was scored as cells that were parasitized and those which had no bees emerge after 90 days. Mortality was observed in four cells (17.39\%): two $(8.69 \%)$ were caused by a cleptoparasite of the family Bombyliidae (Diptera) and in other two (8.69\%), bees died before completing their development.

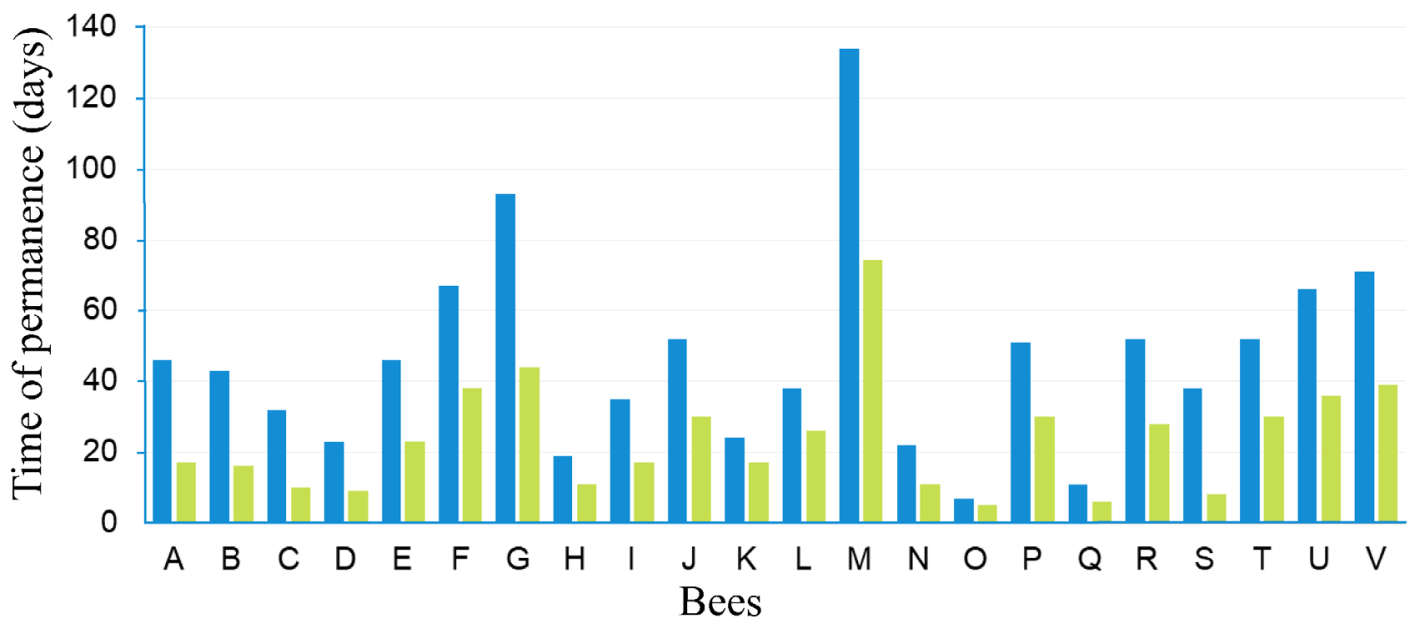

Fig. 2. Time of permanence of Euglossa cordata (Linnaeus, 1758) females (A-V) inside the boxes (green) during the period of study (blue), July 2013 to January 2014, in Fortaleza, CE, Brazil. 
Tab. I. Number of days each Euglossa cordata (Linnaeus, 1758) female (A-V) remained in each box (B1-B12) during the study (July 2013 to January 2014, in Fortaleza-CE, Brazil) and their box of origin.

\begin{tabular}{|c|c|c|c|c|c|c|c|c|c|c|c|c|c|c|c|}
\hline \multirow{2}{*}{ Bee } & \multicolumn{12}{|c|}{ Permanence of bees in numbered boxes (B1-B12) (days) } & \multirow{2}{*}{$\begin{array}{l}\text { Total permanence in } \\
\text { boxes (days) }\end{array}$} & \multirow{2}{*}{$\begin{array}{l}\text { Total permanence during } \\
\text { study (days) }\end{array}$} & \multirow{2}{*}{ Origir } \\
\hline & $\mathrm{B} 1$ & $\mathrm{~B} 2$ & B3 & B4 & B5 & B6 & B7 & B8 & B9 & $\mathrm{B} 10$ & B11 & $\mathrm{B} 12$ & & & \\
\hline A & & 6 & & 6 & 5 & & & & & & & & 17 & 46 & B1 \\
\hline B & & & & & 1 & & & 15 & & & & & 16 & 43 & - \\
\hline $\mathrm{C}$ & & & 1 & 2 & 6 & & & 1 & & & & & 10 & 32 & - \\
\hline $\mathrm{D}$ & & 7 & & 2 & & & & & & & & & 9 & 23 & - \\
\hline E & & & 4 & 15 & 4 & & & & & & & & 23 & 46 & - \\
\hline $\mathrm{F}$ & & 1 & 2 & 3 & 32 & & & & & & & & 38 & 67 & - \\
\hline $\mathrm{G}$ & 23 & 1 & & & & & & 20 & & & & & 44 & 93 & - \\
\hline $\mathrm{H}$ & & 1 & 1 & 3 & & & & & 6 & & & & 11 & 19 & - \\
\hline I & & 4 & 1 & 5 & 6 & & & 1 & & & & & 17 & 35 & - \\
\hline $\mathrm{J}$ & & 3 & & 12 & 2 & 1 & 1 & 11 & & & & & 30 & 52 & B8 \\
\hline K & & 2 & 12 & 3 & & & & & & & & & 17 & 24 & - \\
\hline $\mathrm{L}$ & & & & 2 & & & & & 24 & & & & 26 & 38 & - \\
\hline $\mathrm{M}$ & 1 & 53 & 9 & 10 & & & & & 1 & & & & 74 & 134 & B1 \\
\hline $\mathrm{N}$ & 6 & & 4 & & & 1 & & & & & & & 11 & 22 & - \\
\hline $\mathrm{O}$ & & & & & & & & & 5 & & & & 5 & 7 & B9 \\
\hline $\mathrm{P}$ & 2 & & & & 26 & & & & 1 & 1 & & & 30 & 51 & - \\
\hline Q & & & & 1 & 4 & & & & 1 & & & & 6 & 11 & B4 \\
\hline $\mathrm{R}$ & & & & & & 15 & 12 & & & & & 1 & 28 & 52 & B8 \\
\hline $\mathrm{S}$ & & & & 2 & 4 & & & & & & 2 & & 8 & 38 & - \\
\hline $\mathrm{T}$ & 2 & 28 & & & & & & & & & & & 30 & 52 & - \\
\hline $\mathrm{U}$ & 31 & 1 & 1 & & & & & & 2 & & 1 & & 36 & 66 & - \\
\hline $\mathrm{V}$ & & & & & & & & & & 33 & & 6 & 39 & 71 & B2 \\
\hline
\end{tabular}

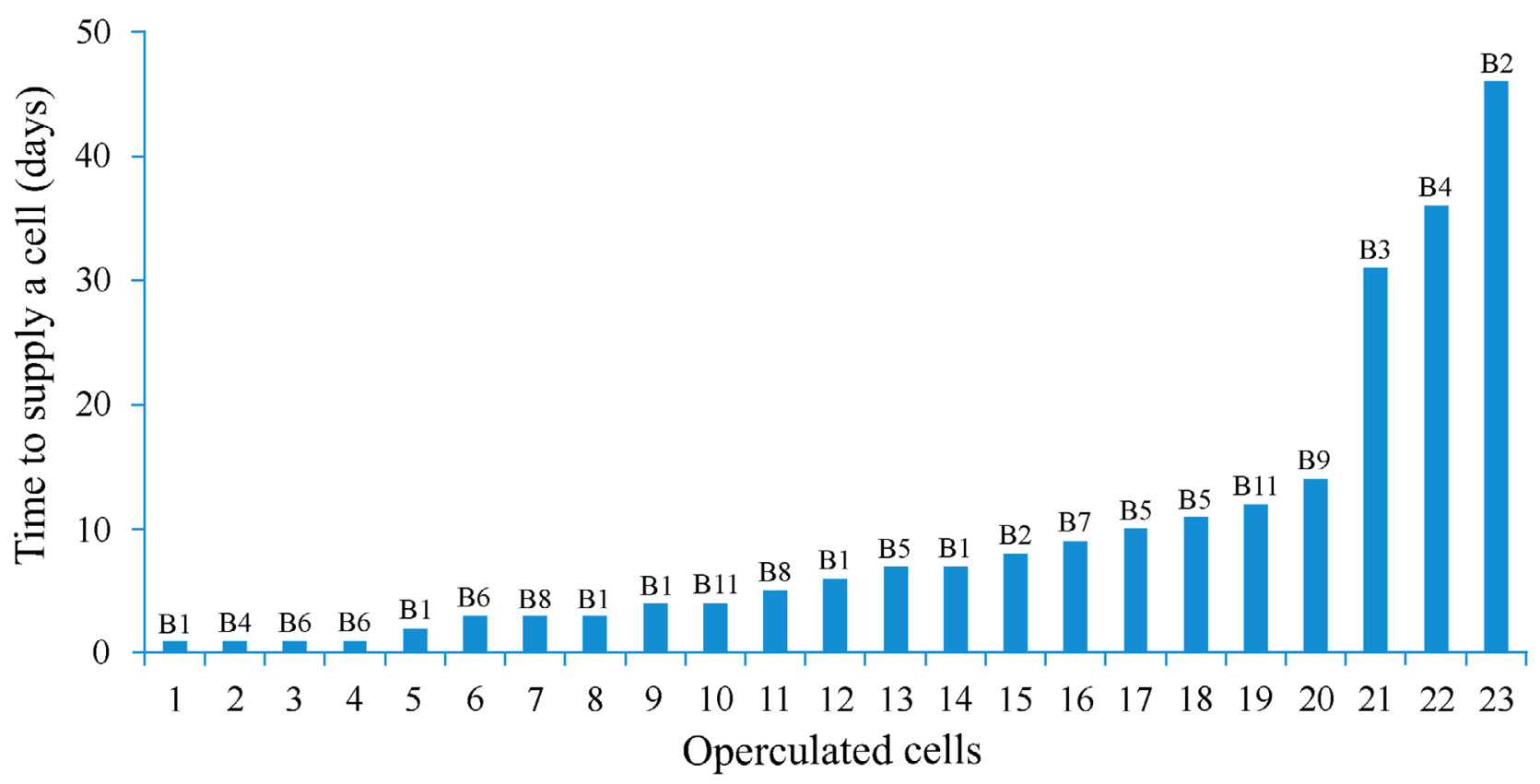

Fig. 3. Number of days taken by females Euglossa cordata (Linnaeus, 1758) to supply a cell (July 2013 to January 2014, in Fortaleza, CE, Brazil). Box numbers are B1-B12.

Permanence of bees. The number of days bees remained in the study ranged from 7 to 134 days (Tab. I). Each bee was followed until the last day it was seen in one of the boxes. The average time of residence inside boxes was shorter than the average time of permanence during the study, even so, bees spent on average $51.04 \%$ inside the boxes.
Nest alternation and bee fidelity. Bees did not live all their lives inside a single nest box. The number of boxes used by the bees (Fig. 4) shows that the majority of them $(72.7 \%)$ used three or more boxes. We found that 18 out of 22 marked bees $(81.8 \%)$ spent more than $50 \%$ of their days inside a single nest (Fig. 5). 


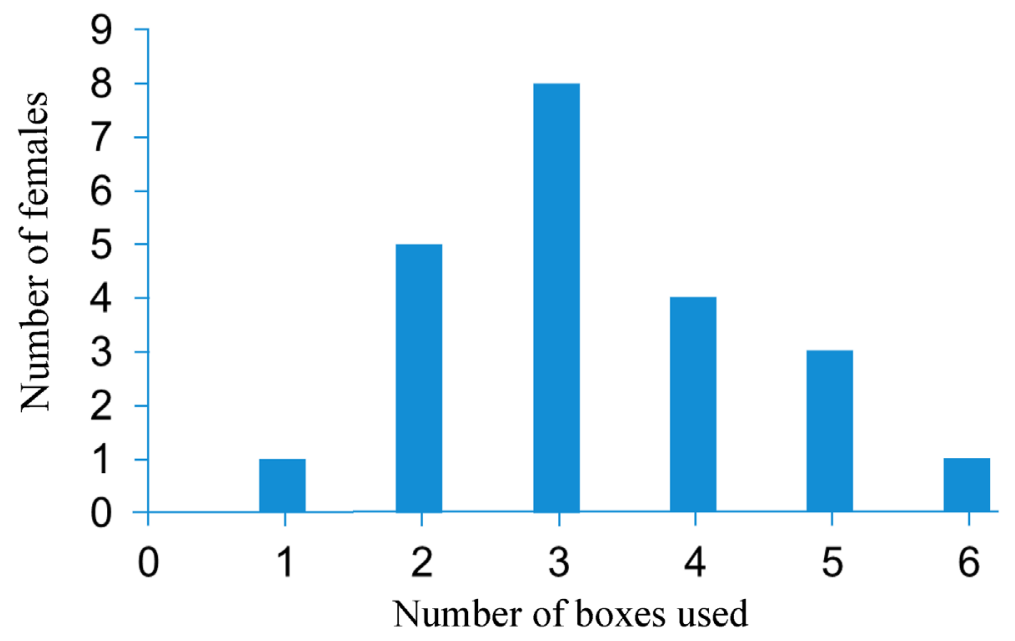

Fig. 4. Number of boxes used by a Euglossa cordata (Linnaeus, 1758) female during the period of study (July 2013 to January 2014), in Fortaleza, CE, Brazil.

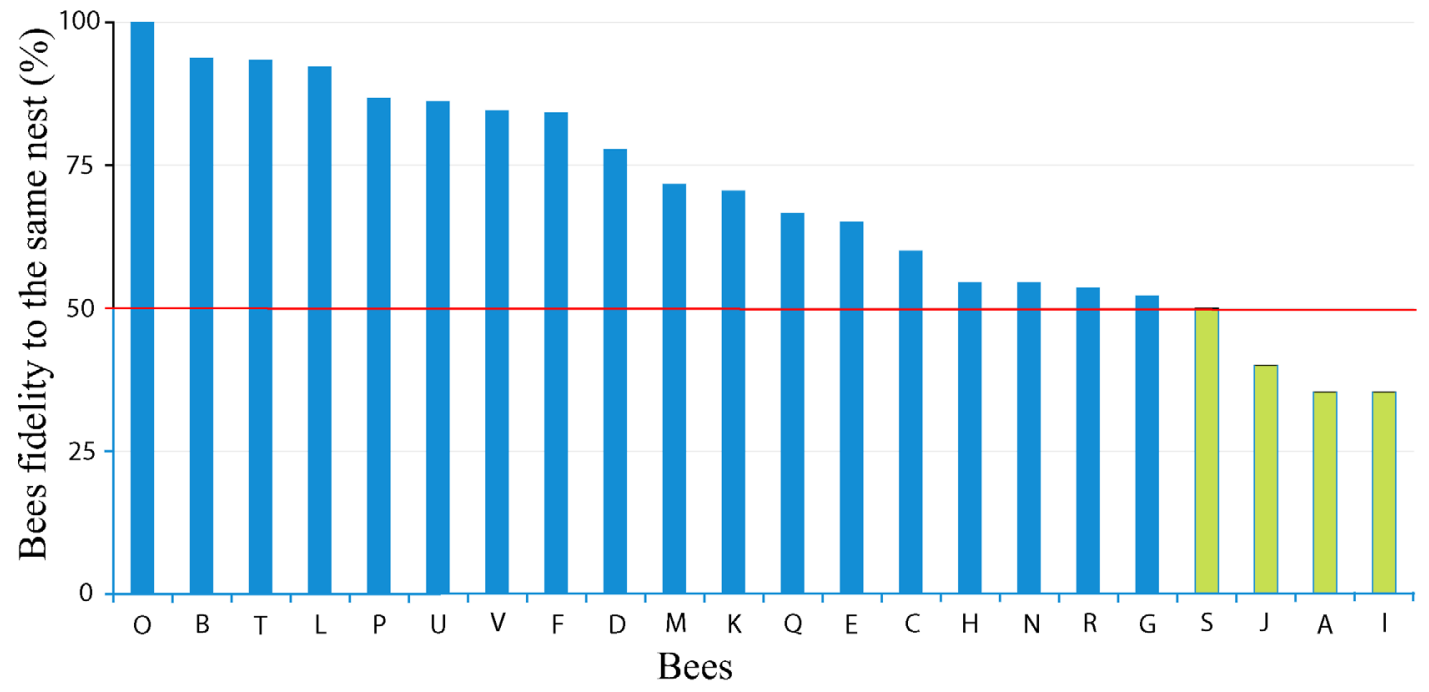

Fig. 5. Percentage of time spent by each bee inside the box in which it remained more days. It represents nest fidelity (residency) of each Euglossa cordata (Linnaeus, 1758) individual (from July 2013 to January 2014, in Fortaleza, CE, Brazil).

\section{DISCUSSION}

In our study, up to three bees were seen in the same box, unlike the finding of Augusto \& Garófalo (2011), who saw up to five bees. This may be related both to the level of sociality (primitively eusocial or communal), as well as to the different sizes of the boxes used for these studies. The smaller space of our boxes perhaps limited the number of individuals in the same nest. However, the number of reactivations in the same nest can also influence the number of females present at the same time, because when subordinate females and their sisters emerge the dominant female may be present in the nest.

Another factor that may have influenced our results is the period of observation, since Augusto \& GARófalo (2011) observed throughout the morning and afternoon shifts, and we made direct observations of presence or absence in the late afternoon, after all bees were presumably in the nest.
In our study, the large range in time needed to supply a brood cell may be related to several factors, among them, the search for better resources, which at some times are available in greater amounts than in others. Another factor is death or abandonment of nest by the founder bee. Such interruption of supply may increase time to provision a cell, or even leave it prone to be parasitized. Furthermore, an unfinished cell may be subject to the time to provision a brood cell by the next bee that continued the work (for example, cell number 23 took 46 days to be finished, in which it had three reactivations by different bees) (GARÓFALO et al., 1998; Garófalo \& Rozen, 2001).

The alternation of nests, when the bee might be supplying more than one cell or not, can also influence the total provisioning time. Based on some studies on solitary bees, they are likely to construct more than one nest at a time and this behavior may influence the time of provisioning a cell, in addition to the distance between these nests, which 
causes the bee to adjust its nesting behavior accordingly with each location (REgO et al., 2006; TeIXEIRA et al., 2011).

The period of brood development was relatively short when compared to studies of E. annectans, E. townsendi Cockerell 1904 and E. melanotricha Moure, 1967 (GARÓFALO et al., 1998; Augusto \& GaróFAlo, 2004; ANDRADE-SiLVA \& NASCIMENTO, 2012), where females took an average of 61 to 83 days to develop. According to Howe (1967), and many other studies, higher temperatures increase insect metabolic rate and shorten development. However, we did not evaluate whether this climatic variable had any influence on our results.

Regarding the emergence of bees, our results differed from those reported in other studies with $E$. cordata (Garófalo, 1985; Augusto \& Garófalo, 2011), because only females emerged from finished brood cells. According to MiCHENER (1974) bees can control sex of their offspring, however, the factors involved in their decision to fertilize an egg are still unknown.

Females generally need a greater amount of food to develop than males, and because of this they are produced preferentially in periods with greater abundance of resources (Silva et al., 2001). But, according to Michener (1974) and CAPALDI et al. (2007) the sex ratio in bee offspring is generally divergent, because it depends on several factors, such as seasonality, climate, availability of substrates, floral resources, parasitism, and breeding mortality. TORCHIO \& TePEDINo (1980) maintain sex ratio can be considered an annual break-even point, because if more investment is made in offspring favoring a sex at some point, that proportion should be corrected in subsequent generations. However, we cannot determine which factors affected sexual proportion of $E$. cordata in this study, and a longer follow-up period is necessary, but Boff et al. (2017) found for E. annectans that in some generations only females emerge and even those generations with emergence of males, or individuals of unknown sex, there was a prevalence of females. ANDRADE et al. (2016) noticed that nests with genetically related females of E. melanotricha (sibling or matrifilial), dominant bees produced about $60 \%$ females, while subordinate bees produced about $25 \%$. In unrelated females, the production of males or females was equivalent. Thus, dominant females appear to be able to evaluate reproduction among nestmates and to selectively remove more or less eggs according to their self-interest.

With regard to parasitism, the Bombyliidae, as observed in this study, have already been reported for $E$. cordata (GARófalo, 1992), E. annectans (GARófalo et al., 1998), E. townsendi (Augusto \& Garófalo, 2004), and E. viridissima (Сосом РесH et al., 2008). The female parasitoids leave eggs near the nest entrance and when its larva hatches, it finds the host cell and feeds on the immature and also pollen (GerLing \& HermanN, 1976; Boesi et al., 2009). Low frequency of parasitism in this study may be related to the actual process of nest reactivation, or even with the presence of one or more females in the nest (FrEIRIA et al. 2017b). This becomes more likely when we observed that bee $\mathrm{M}$, for example, used three boxes to provision four cells, three of them almost at the same time. The first two cells were built in different boxes (seven days for cell 21 in box 3 and six days for cell 22 in box 4 ) and the last two cells were provisioned in box 2 (eight days for cell 15 and 6 days for cell 23). The constant alternation between boxes to supply more than one cell in parallel could have contributed to Bombyliidae parasitism of cells 21 and 22 because each of these boxes was left unprotected while bee $\mathrm{M}$ worked in the other box. OTERo (2001) and Soucy et al. (2003) had already observed that E. nigropilosa and E. hyacinthina nests may experience more parasitism when unattended by adult females, as we observed here for cells 21 and 22, while cell 23 was not parasitized. The last cell likely escaped parasitism because four bees participated in its provisioning during successive nest reactivations. Also, coexistence with other adult females in a same nest can be beneficial as it allows a greater vigilance against attacks of parasites or predators, since solitary nests are more susceptible to being attacked by natural enemies (RoubiK, 1990; FreIRIA et al., 2017b).

The mean time bees remained in the nests in this study, 46.45 days, was similar to that found by DoDson (1966), who studied this aspect in E. ignita. In his data he found differences for males and females, as males lived up to only 13 or 14 days, while females lasted a much longer period, from 30 to 60 days. It is worth mentioning that DoDson (1966) provided essences for males, and some of them survived more than 31 days in captivity. ACKERMAN \& Montalvo (1985) wrote that marked, free-living male individuals of Eulaema nigrita Lepeletier, 1841, Eulaema meriana (Olivier, 1789) and Exaerete frontalis (Guérin, 1844) may live approximately 75, 120 and 150 days, respectively.

Some factors can influence longevity of these bees, even if they have ended reproductive activities. One could be nutrition. The deficiency of some nutrients can compromise health and, consequently, bee longevity (BEHMER \& JOERN, 2008; Pinheiro et al., 2009; Augusto \& GaróFalo, 2011; VALDO et al., 2015). Our study was carried out in a small forest fragment where diversity and abundance of flower species is reduced.

In this study, females spent on average $51 \%$ of their time inside boxes. Since they were not found in any box for a few days and then returned, they were probably nesting elsewhere, or even visiting other nests in the vicinity. Literature data are still scarce on information about nest alternation by E. cordata. However, our results suggest that bees share their nests or even that a female may be involved with more than one nest, regardless of dominant-subordinate relationship, because most bees were seen inhabiting more than three boxes during the observation period, with $36.3 \%$ of them using three boxes. However, in $93.34 \%$ of the observations, bees were alone in the boxes, that is, a single female was responsible for the nest during a certain period of time, not sharing the nest with nest mates. Therefore, although it was not possible to observe the behavior of females inside the nests, we can assume here that a solitary behavior prevailed. However, these observations do not 
exclude the possibility of interactions between more than one female during the day, or other moments when two or three bees were seen in the same nest.

On the other hand, when more than one bee try to impose their dominance over the others, it may occur a tug-of-war or parental parasitism in relation to dispute by egg-laying, as reported to E. annectans (Boff et al., 2017). Even if it is not an opportunistic behavior, E. cordata can assume the behavior of a nest usurper. FreIRIA et al. (2017a) reported a $E$. cordata female of unknown origin that invaded a nest and killed the dominant female, thus inheriting both the nest and a subordinate female. Furthermore, through Mendelian analyzes they realized that a bee that emerged from one closed cell two days after the unknown female took over the nest was likely its daughter. This result suggest that the usurpating female had already interacted somehow with the former dominant female in its nest well before.

Because nest boxes are identical and grouped close together (see Methods), females may accidently enter another female's or colony's nest. This can be explained in females who visited a different nest for one to a few days. However, for those who spent most of their days in another nest, it would indicate that they were provisioning cells in parallel (bees E, M and R, for example) or contributing to the maintenance of that nest. Therefore, regardless of the relationship of subordination or dominance among bees in the present study, the fact that there is such alternation of nests may indicate that attempts are being made to increase the female reproductive fitness and the proximity of our nesting boxes may have made such behavior more likely to take place.

Euglossa cordata showed a relatively high fidelity to a single nest but interacted with other nests and females. In doing that, the dominant female gets help to build its cells faster and the constant presence of at least one female in the nest prevents cleptoparasites and other threats to an empty nest while its owner is away. This behavior may be a reproductive strategy and deserves further study.

Acknowledgments. We thank the anonymous referees, Dr. David W. Roubik for considerations on the study and revision of English language, together with Dr. Favízia Freitas de Oliveira for the identification of bee species, Conselho Nacional de Desenvolvimento Cientifico e Tecnológico - CNPq for a Productivity in Research Sponsorship to BM Freitas (\#302934/2010-3) and Fundo Brasileiro para a Biodiversidade (FUNBIO) for grants awarded during this study.

\section{REFERENCES}

Ackerman, J. D. \& Montalvo, A. 1985. Longevity of Euglossine bees. Biotropica 17(1):79-81.

Andrade, A. C. R.; Miranda, E. A.; Del lama, M. A. \& Nascimento, F. S. 2016. Reproductive concessions between related and unrelated members promote eusociality in bees. Scientific Reports 6:26635.

Andrade-Silva, A. C. R. \& Nascimento, F. S. 2012. Multifemale nests and social behavior in Euglossa melanotricha (Hymenoptera, Apidae, Euglossini). Journal of Hymenoptera Research 26:1-16.

Augusto, S. C. \& Garófalo, C. A. 2004. Nesting biology and social structure of Euglossa (Euglossa) townsendi Cockerell (Hymenoptera, Apidae, Euglossini). Insectes Sociaux 51:400-409.
Augusto, S. C. \& Garófalo, C. A. 2007. Nidificação de Euglossa (Euglossa) melanotricha Moure (Hymenoptera: Apidae) no solo do Cerrado. Neotropical Entomology 36(1):153-156.

Augusto, S. C. \& Garófalo, C. A. 2011. Task allocations and interactions among females in Euglossa carolina nests (Hymenoptera, Apidae, Euglossini). Apidologie 42:162-173.

Behmer, S. T. \& JoERn, A. 2008. Coexisting generalist herbivores occupy unique nutritional feeding niches. Proceedings of the National Academy of Sciences 105:1977-1982.

Boesi, R.; Polidori, C. \& Andrietti, F. 2009. Searching for the right target: oviposition and feeding behavior in Bombylius bee flies (Diptera: Bombyliidae). Zoological Studies 48:141-150.

Boff, S. \& Alves-Dos Santos, I. 2018. Cavities in bromeliad stolons used as nest sites by Euglossa cordata (Hymenoptera, Euglossini). Journal of Hymenoptera Research 62:33-44.

Boff, S.; Forfert, N.; Paxton, R. J.; Montejo, E. \& Quezada-Euan, J. J. G. 2015. A behavioral guard caste in a primitively eusocial orchid bee, Euglossa viridissima, helps defend the nest against resin theft by conspecifics. Insectes Sociaux 62(2):247-249.

Boff, S.; SAITO, C. A. \& SANTOS, I. A. 2017. Multiple aggressions among nestmates lead to weak dominance hampering primitively eusocial behaviour in an orchid bee. Sociobiology 64(2):202-211.

Capaldi, E.; Flynn, C. J. \& Wcislo, W. T. 2007. Sex ratio and nest observations of Euglossa hyacinthina (Hymenoptera, Apidae, Euglossini). Journal of the Kansas Entomological Society 80:395-399.

Carvalho-Filho, F. S. \& Oliveira, F. F. 2017. Notes on the nesting biology of five species of Euglossini (Hymenoptera: Apidae) in the Brazilian Amazon. Entomobrasilis 10(1):64-68.

Сосом Ресн, M. E.; May-Itzá, W. J.; Medina, L. A. M. \& QuezadaEuÁn, J. J. G. 2008. Sociality in Euglossa (Euglossa) viridissima Friese (Hymenoptera, Apidae, Euglossini). Insectes Sociaux 55:428-433.

Dodson, C. H. 1966. Ethology of some bees of the tribe Euglossini (Hymenoptera: Apidae). Journal of the Kansas Entomological Society 39:607-629.

Freiria, G. A.; Garófalo, C. A. \& Del Lama, M. A. 2017a. The primitively social behavior of Euglossa cordata (Hymenoptera, Apidae, Euglossini): a view from the perspective of kin selection theory and models of reproductive skew. Apidologie 48(4):523-532.

Freiria, G. A.; Rocha-Filho, L. C.; Del lama, M. A. \& Garófalo, C. A. 2017b. Surrounded by foes: Parasitism in Euglossa spp. (Apidae, Euglossini) caused by six species of natural enemies. Journal of Apicultural Research 56(3):255-261.

Garófalo, C. A. 1985. Social structure of Euglossa cordata nests (Hymenoptera: Apidae: Euglossini). Entomologia Generalis 11:77-83.

GARÓFALO, C. A. 1992. Comportamento de nidificação e estrutura de ninhos de Euglossa cordata (Hymenoptera: Apidae: Euglossini). Revista Brasileira de Biologia 52: 187-198.

Garófalo, C. A.; Evandro, C.; Augusto, S. C.; Jesus, B. M. V. \& Serrano, J. C. 1998. Nest structure and communal nesting in Euglossa (Glossura) annectans Dressler (Hymenoptera, Apidae, Euglossini). Revista Brasileira de Zoologia 15:589-596.

Garófalo, C. A. \& Rozen, J. G. 2001. Parasitic Behavior of Exaerete smaragdina with descriptions of its mature oocyte and larval Instars (Hymenoptera: Apidae: Euglossini). American Museum Novitates 3349:1-26.

Gerling, D. \& Hermann, H. 1976. The oviposition and life cycle of Anthrax tigrinus (Dipt.: Bombyliidae) a parasite of carpenter bees (Hym.: Xylocopidae). Entomophaga 21(3):227-233.

Howe, R. 1967. Temperature effects on embryonic development in insects. Annual Review of Entomology 12:15-42.

iPECE - Instituto de Pesquisas e Estratégia Econômica do Ceará. 2016. Perfil básico municipal. Fortaleza - CE. Available at $<\mathrm{http} / / /$ www.ipece.ce.gov.br/perfil_basico_municipal/2016/Fortaleza.pdf $>$. Accessed on 8 Mar 2018.

MiCHENER, C. D. 1974. The social behavior of the bees: a comparative study. Cambridge, Harvard University Press. 418p.

Michener, C. D. 2007. The Bees of the world. 2ed. Baltimore, Johns Hopkins University Press. 953p.

Moure, J. S.; Melo, G. A. R. \& Faria JR., L. R. R. 2012. Euglossini Latreille, 1802. In: Moure, J. S.; Urban, D. \& Melo, G. A. R. orgs. Catalogue of Bees (Hymenoptera, Apoida) in the Neotropical 
Region - online version. Available at $<$ http://www.moure.cria.org.br/ catalogue $>$. Accessed on 22 Jan 2018.

Otero, J. T. 2001. Monodontomerus argentinus Brethes (Hymenoptera: Torymidae): a new parasitoid of Euglossa nigropilosa Moure (Hymenoptera: Apidae: Euglossinae). The Pan-Pacific Entomologist 77:57-60.

Pinheiro E. B.; Maracajá P. B.; Mesquita L. X.; Soto-Blanco B. \& Oliveira Filho R. B. 2009. Efeito de diferentes alimentos sobre a longevidade de operárias de abelhas Jandaíra em ambiente controlado. Revista Verde de Agroecologia e Desenvolvimento Sustentável 4(3):50-56.

Ramírez, S.; Dressler, R. L. \& Ospina, M. 2002. Abejas Euglossina (Hymenoptera, Apidae) de la región neotropical: Listado de especies con nota sobre su biología. Biota Colombiana 3:7-118.

Rego, M. M. C.; Albuquerque, P. M. C.; Ramos, M. C. \& Carreira, L. M. 2006. Aspectos da Biologia de Nidificação de Centris flavifrons (Friese) (Hymenoptera: Apidae, Centridini), um dos Principais Polinizadores do Murici (Byrsonima crassifolia L. Kunth, Malpighiaceae), no Maranhão. Neotropical Entomology 35(5):579-587.

RoubiK, D. W. 1990. A mixed colony of Eulaema (Hymenoptera: Apidae), natural enemies, and limits to sociality. Journal of the Kansas Entomological Society 63:150-157.
RoubiK, D. W. \& Hanson, P. E. 2004. Orchid Bees of Tropical America: Biology and Field guide. Heredia, INBio Press. 370p.

SANTOS, C. F. \& BofF, S. 2010. Subtle visits despite guards: Theft from nest of stingless bee (Meliponini) by orchid bee (Euglossini). Entomological Research 40:233-235.

Silva, F. O.; Viana, B. F. \& Neves, E. L. 2001. Biologia e arquitetura de ninhos de Centris (Hemisiella) tarsata Smith (Hymenoptera: Apidae: Centridini). Neotropical Entomology 30:541-545.

SKov, C. \& WILEY, J. 2005. Establishment of the neotropical orchid bee Euglossa viridissima (Hymenoptera: Apidae) in Florida. Florida Entomologist, 88(2):225-227.

SOUCY, S. L.; GIRAY, T. \& RoubIK, D. W. 2003. Solitary and group nesting in the orchid bee Euglossa hyacinthine (Hymenoptera, Apidae). Insectes Sociaux 50:248-255.

Teixeira, F. M.; Schwartz, T. A. C. \& Gaglianone, M. C. 2011. Biologia da Nidificação de Megachile (Moureapis) benigna Mitchell. EntomoBrasilis 4(3):92-99.

Torchio, P. F. \& TEPEDINO, V. J. 1980. Sex ratio, body size and seasonality in solitary bee, Osmia lignaria propinqua Cresson (Hymenoptera: Megachilidae). Evolution 34:993-1003.

Valdo, A. D.; ToOker, J. F.; Grozinger, C. M. \& Patch, H. M. 2015. Bee nutrition and floral resource restoration. Current Opinion in Insect Science 10:133-141. 